Ilmu Dakwah: Academic Journal for Homiletic Studies Vol 10 No 1 Januari-Juni 2016 p-ISSN 1693-0843

\title{
Kebijakan Redaksi Media Dakwah dalam Membangun Kerukunan Ummat Beragama di Jawa Barat
}

\author{
Roni Tabroni \\ Universitas Sangga Buana YPKP, Bandung \\ roni_tepas@yahoo.com
}

\begin{abstract}
This study examines the media dakwah in the form of mosque bulletin relation to barmony religious community in West Java. Some years ago the media reported that West Java is the province with the bighest rate of inter-religious conflict in Indonesia. Resistance to physical violence is very likely one of them caused by the low level of understanding of the ummah against religious insight. This research is important to assess whether in the form of bulletin dakwah media has a role in preventing conflict, or even contribute to lower levels of religious harmony in West Java community. The method research is qualitative with descriptive approach. By taking Uswah bulletin issued by Pusdai West Java and bulletins issued by the Gema Mujabidin by Muhammadiyah West Java. The study produced findings on historical aspects, management, and message bulletin dakwah. Content that has been developed and become a mainstream issue in the two bulletins in the form of community enlightenment through the messages of Islam are moderate and more peaceful. The second bulletin became a tool for community education about the importance of tolerance and Islamic deeper insight.
\end{abstract}

Keyword: Bulletin, Dakwah, Islam, Insight, Education

\section{Abstrak}

Penelitian ini mengkaji tentang media dakwah berupa bulletin mesjid kaitannya dengan kerukunan ummat beragama di Jawa Barat. Beberapa tahun ke belakang media massa memberitakan bahwa Jawa Barat merupakan provinsi dengan tingkat konflik antar agama tertinggi di Indonesia. Resistensi hingga terjadinya kekerasan fisik sangat mungkin salah satunya disebabkan oleh rendahnya tingkat pemahaman ummat terhadap wawasan keagamaan. Penelitian ini menjadi penting untuk mengkaji apakah media berupa bulletin dakwah memiliki peran dalam mencegah terjadinya konflik atau bahkan turut menurunkan tingkat kerukunan ummat beragama di Jawa Barat. Metode yang digunakan dalam penelitian ini yaitu kwalitatif dengan pendekatan deskriptif. Dengan mengambil bulletin Uswah yang diterbitkan oleh Pusdai Jawa Barat dan bulletin Gema Mujahidin yang diterbitkan oleh Muhammadiyah Jawa Barat. Penelitian ini menghasilkan temuan tentang aspek kesejarahan, pengelolaan, dan pesan bulletin dakwah. Konten yang selama ini dikembangkan dan menjadi isu mainstream di dua bulletin itu berupa pencerahan ummat lewat pesan-pesan keislaman yang cukup moderat dan lebih damai. Kedua bulletin ini justru menjadi alat untuk pendidikan ummat tentang pentingnya toleransi dan wawasan keislaman yang lebih mendalam.

Kata Kunci: Bulletin, Dakwah, Islam, Pencerahan, Pendidikan

Naskah diterima: 6 Sept 2016, direview 1 Nov 2016, disetujui: 14 Nov 2016

Ilmu Dakwah: Academic Journal for Homiletic Studies, Vol 10 No 1 | Jan-Juni 2016 
Kebijakan Redaksi Media Dakwah dalam Membangun ...

\section{PENDAHULUAN}

Kasus konflik horizontal dengan motif agama, khususnya terkait dengan isu Ahmadiyah selalu terjadi. Jawa Barat sebagai provinsi dengan tingkat konflik agama paling tinggi di Indonesia, juga seringkali diwarnai persoalan perbedaan pemahaman yang mengakibatkan konflik antar pemeluk agama. Selain itu, Jawa Barat juga memiliki basis Jamaah Ahmadiyah Indonesia (JAI) sangat besar yaitu di Kuningan, termasuk beberapa daerah lainnya. Dengan keberadaan basis JAI ini mau tidak mau, Jawa Barat memiliki tingkat kerawanan sangat tinggi. Selain itu beberapa daerah di luar Kuningan, seperti di Tasikmalaya, Garut, Purwakarta, Bandung, Bogor dan beberapa daerah lainnya tercatat menjadi basis penyebaran Ahmadiyah.

Beberapa daerah telah merubah perbedaan pemahaman ini menjadi sebuah aksi fisik sehingga menimbulkan anarkisme massa yang merugikan baik secara materil maupun mental masyarakat yang lain. Ada dugaan, eskalasi semakin tinggi ketika ada SKB tiga menteri terkait Ahmadiyah. Secara khusus, Gubernur Jawa Barat telah mengeluarkan Pergub Ahmadiyah tahun 2011, yang sedikit banyak berpengaruh terhadap kondisi ummat di tingkat bawah. Selain Ahmadiyah, Jawa Barat juga rentan karena potensi yang lain seperti Syi'ah, kristenisasi, nabi-nabi palsu, bahkan ada beberapa yang mengaku tuhan.

Namun, yang juga tidak kalah pentingnya dalam konteks kerukunan adalah juga bagaimana para Ulama atau Ustad memberikan pemahaman kepada jamaahnya lewat sebuah media dakwah yang sangat efektif. Media dakwah berupa bulletin Jum'at yang tersebar di mesjidmesjid di Jawa Barat sedikit banyak memberikan pengaruh terhadap pemahaman masyarakat dalam menanggapi berbagai fenomena sosial, termasuk terkait dengan pemahaman Ahmadiyah.

Media dalam konteks dakwah memiliki tingkat pengaruh cukup signifikan dalam menyampaikan pesan-pesan dakwah, apakah lebih cenderung toleran atau sebaliknya. Walaupun bulletin Jum'at ukurannya sangat kecil dan terbitnya satu minggu sekali, namun dalam konteks media massa, bulletin Jum'at sangat efektif dalam mempersuasi massa (jamaah jumat) dalam menyampaikan sebuah pesan baik berupa ajakan maupun pengertian tentang segala hal. Di sinilah para Ulama dan Ustad yang ada di mesjid (sebagai ruang redaksi) menentukan isu yang akan diangkat dan menjadi konsumsi publik. Dalam konteks dakwah, inilah yang disebut dengan dakwah bil Qalam.

Ilmu Dakwah: Academic Journal for Homiletic Studies, Vol. 10 No.1 | Jan-Juni 2016 
Istilah Dakwah Bil Qalam mungkin belum terlalu memasyarakat di kalangan ummat Islam secara umum. Hal ini sangat berbeda misalnya dengan kata Dakwah Bil Lisan atau Dakwah Bil Hal. Penggunaan kata Qalam sendiri, menurut Asep SM. Romli (2003), merujuk kepada firman Allah SWT, "Nun, perhatikeanlah Al-Qalam dan apa yang dituliskannya" (Q.S. Al-Qalam: 1). Dengan dasar ayat tersebut, maka jadilah Dakwah Bil Qalam sebagai konsep dakwah melalui pena, yaitu dengan membuat dulisan di media massa.

Karena menyangkut tulisan, maka Dakwah Bil Qalam bisa diidentikkan dengan istilah Dakwah Bil Kitabah (dakwah melalui tulisan). Namun dalam aktivitas dakwah di media ini, Asep lebih memilih Qalam dengan alasan kata ini memiliki kesan lebih agresif ketimbang Kitabah (tulisan). Pena menunjukkan subjek, senjata, atau alat. Tulisan adalah objek, hasil, atau produk goresan pena.

Pada era informasi sekarang ini yang ditandai dengan maraknya media massa sebagai sarana komunikasi massa dan alat pembentuk opini publik, para mubaligh, aktivits dakwah, dan umat Islam pada umumnya, menurut Asep harus mampu memanfaatkan media massa untuk melakukan Dakwah Bil Qalam. Mereka dapat menyapaikan pesan-pesan yang mengarah pada kerukunan, namun juga bisa sebaliknya.

Sebagai bagian dari media massa, bulletin dapat mengarahkan audiens atau pembaca untuk melakukan sesuatu seperti yang diinginkan oleh pihak media. Walaupun ada kondisi dimana publik tidak bisa diarahkan baik opini maupun perilakunya, namun pihak media tetap berharap bahwa apa yang disampaikannya akan diserap dan diamalkan oleh pembacanya.

Dalam konteks bulletin Jum'at, setiap pengelola bulletin tentu memiliki kepentingan dalam menyampaikan idiologinya. Media yang sangat sederhana bisa menjadi saluran yang sangat efektif dalam menciptakan kerukunan ummat beragama. Sehingga dengan kekuatan pengaruhnya bulletin Jum'at dapat dimanfaatkan untuk kepentingan apapun termasuk dalam konteks kerukunan.

Walaupun agenda setting dianggap teori lama, dimana pola komunikasi masih satu arah dan bersifat top down, namun masih relevan untuk melihat sejauh mana para redaktur bulletin Jum'at dalam penelitian ini memiliki kewenangan penuh dalam menentukan konten bulletin nya. Sehingga dengan kewenangannya itu, para redaktur bulletin 
cenderung lebih dominan dan bebas memilih topik dan membawa ke arah mana bulletin akan di bawa.

Selain para Ustad atau Ulamanya sendiri, para pengurus Mesjid memiliki peran penting dalam menyampaikan pesan-pesan dakwah. Sebab berdasarkan riset sementara, sangat jarang jika media massa yang dikelola oleh mesjid, seperti bulletin Jum'at dikelola oleh seorang Ustad secara langsung. Karenanya, pengelola bulletin ini lebih penting untuk menyampaikan pesan-pesan dakwah tersebut daripada menyerahkan tanggungjawab ini kepada seorang Ustad.

Dalam konteks dakwah, media mini seperti bulletin memiliki tempat strategis untuk menjadi saluran dakwah kepada jamaahnya. Di samping dakwah bil lisan yang dilakukannya, dakwah bil qalam seperti ini memiliki kekuatan selain jamaah dapat menyerapnya dalam kondisi konsentrasi penuh, juga media dakwah itu juga dapat tersebar kepada orang lain yang tidak ikut jum'atan seperti keluarga di rumah atau di kantor. Dengan tingkat dekumentasi yang menjadi kelebihannya (dibanding dakwah bil lisan), media Jum'at ini dapat dibaca lagi di lain waktu jika sesekali masyarakat membutuhkannya.

Kebijakan redaksional di setiap bulletin Jum'at ini menjadi penting mengingat bahwa persoalan bulletin bukan hanya sebagai pekerjaan teknis tetapi juga idiologis. Dengan media bulletin ini pimpinan mesjid dapat menyalurkan idiologinya kepada jamaah, khususnya dalam menyikapi perbedaan pemahaman yang ada di masyarakat. Dalam kajian media, tidak ada sebuah tema yang muncul secara kebetulan. Tentu keseriusan redaksi bulletin berbeda dengan media komersil lainnya.

Dengan demikian dalam konteks kerukunan beragama ini, bulletin jumat memiliki peran yang sangat strategis dalam mengarahkan pemahaman dan perilaku ummat dalam kaitannya dengan kerukunan beragama. Bulletin Jum'at dapat membangun pondasi kerukunan, tetapi pada sisi lain juga dapat menjadi percikan api yang dapat menyulut emosi jamaah sehingga menimbulkan rasa benci dan bergerak untuk melakukan aksi fisik. Untuk itu dalam konteks ini sangat penting kiranya mengkaji keberadaan bulletin jumat yang ada di Jawa Barat, khususnya terkait dengan upaya membangun pemahaman toleransi di kalangan ummat.

Penelitian ini bertujuan untuk mengungkap kondisi keberadaan bulletin Jum'at di Jawa Barat kaitannya dengan persoalan kerukunan ummat beragama. Jika dalam teorinya media massa memberi pengaruh yang cukup besar terhadap para pembacanya, maka asumsinya bulletin Jum'at juga memberikan pengaruh signifikan kepada para pembacanya 
baik yang langsung ada di mesjid dan hadir di saat Jum'atan, maupun masyarakat lain yang turut membaca. Dengan penelitian ini, akan terungkap apakah bulletin Jum'at di Jawa Barat - setidaknya yang menjadi objek penelitian - memberikan konten yang lebih toleran kepada jamaahnya atau justru sebaliknya. Hal ini akan terlihat dari mulai keberadaan bulletin Jum'at tersebut, aspek kebijakan redaksinya, hingga "warna" bulletin yang dakan terlihat dari sisi kontennya.

Metode utama yang digunakan dalam penelitian ini adalah metode kualitatif. Secara sederhana, Moleong (2009) mendefinisikan metode kualitatif sebagai cara untuk mendeskripsikan fenomena sosial. Dengan metode tersebut peneliti dapat mengeksplorasi persoalan dan gejala sosial dengan mendalam (deep investigation). Metode kualitatif ini di gunakan karena beberapa pertimbangan: Pertama, karena metode kualitatif deskriptif sesuai dengan orientasi riset ini, yaitu untuk mendeskripsikan kenyataan. Kedua, metode kualitatif memungkinkan untuk mengamati dan memahami gejala kehidupan komunitas masyarakat sesuai dengan gambaran mereka sendiri. Masyarakat sebagai sumber informasi dan data dijadikan sebagai sumber pokok data penelitian kualitatif. Ketiga, Metode kualitatif memungkinkan untuk melakukan verifikasi dan eksplanasi secara lebih mendalam terhadap objek penelitian. Dengan cara kualitatif investigative, maka dimungkinkan untuk melakukan cross check terhadap realitas yang dianggap berbeda dengan keharusan sebagaimana dalam ketentuan. Keempat, dalam metode kualitatif sebagaian besar data yang dikumpulkan berupa informasi verbal dari sejumlah informan dalam penelitian ini. Keenam, motode kualitatif lebih relevan untuk penelitian fenomena-fenomena kemanusiaan sebagaimana objek pada penelitian ini. Metode kualitatif sanggup mengeksplorasi persoalan sosial secara lebih dalam. Pendekatan kualitatif ini berkaitan erat dengan sifat unik dari realitas sosial dan dunia tingkah laku manusia itu sendiri. Keunikannya bersumber dari hakikat manusia sebagai makhluk psikis, sosial, dan budaya yang mengaitkan makna dan interpretasi dalam bersikap dan beretingkah laku; makna dan interpretasi itu sendiri dipengaruhi oleh lingkungan social, system social, dan budaya. Kompleks sistem makna tersebut secara konstan digunakan oleh seseorang dalam mengorganisasikan segenap sikap dan tingkah lakunya sehari-hari.

Penelitian ini dilakukan pada bulletin Jum'at yang diterbitkan oleh dua mesjid besar di Jawa Barat yaitu Mesjid Pusdai (Islamic Center) Jawa Barat yang mewakili pusat dakwah dan Mesjid Raya Mujahidin mewakili mesjid besar yang dikelola oleh Ormas Islam tingkat Jawa Barat. 
Pemilihan lokasi penelitian ini berdsarkan kepada posisi mesjid tersebut dengan level Jawa Barat baik yang langsung dikelola oleh Pemda Jawa Barat yaitu Pusdai Jabar (Islamic Center) maupun Ormas Islam yaitu Muhammadiyah Jawa Barat (Mesjid Mujahidin). Representasi ini menjadi penting karena kedua mesjid ini mewakili dua unsur yaitu pemerintah dan masyarakat secara langsung. Kendati punya fungsi yang sama yaitu dakwah Islam, namun keduanya punya corak dan karakteristik yang tentunya sangat berbeda, baik pada aspek managerial maupun pola pengembangan dakwahnya dan corak berfikirnya.

Pengambilan mesjid-mesjid ini juga didasarkan pada keberadaan media bulletin yang dimilikinya memiliki tingat penyebaran yang cukup luas. Misalnya, bulletin yang dikelola Pusdai Jabar bisa menjangkau 23 Mesjid baik yang ada di Kota Bandung maupun di Kabupaten Bandung, hingga ke Majalaya. Sedangkan bulletin yang dikelola oleh Mujahidin sendiri bisa mencapai 12 Mesjid. Tingkat penyebaran ini tentu saja sangat terkait dengan pola penyebaran pesan-pesan yang ada di dalamnya. Sehingga dapat diasumsikan bahwa kedua media yang dikelola dua mesjid ini dapat memberikan pengaruh terhadap masyarakat luas. Dalam pengelolaan media bulletin Jum'at, oplah dan penyebaran seperti ini tergolong besar dan sangat jarang sekali terjadi di mesjid-mejid lainnya.

\section{HASIL DAN PEMBAHASAN}

\section{Bulletin Uswah Pusdai Jabar}

Bulletin Uswah Pusdai Jabar mulai diterbitkan pada tahun 1999. Pada tahun ini bulletin Uswah Pusdai Jabar berada di bawah bidang Pengembangan Informasi.Keberadaan Bulletin Uswah Pusdai Jabar pada awalnya sangat sederhana. Bulletin ini tidak terlalu variatif, rubrik hanya terdiri dari kajian utama dan informasi kegiatan Pusdai Jabar. Tambahan konten paling juga lebih kepada informasi kencleng yang selalu diinformasikan setiap minggunya.

Para pengelola awal Bulletin Uswah Pusdai Jabar, tidak banyak inprovisasi sehingga kondisi bulletin ini realtif monoton. Namun, sebagai sarana dakwah, keberadaan dan konsistensi untuk tetap terbit saja bulletin ini lebih dari cukup. Sebab pada tahun tersebut, bulletin dakwah yang diterbitkan oleh mesjid realtif sulit.

Sebagai pengembangan, Bulletin Uswah Pusdai Jabar pernah terbit dalam versi jurnal pada tahun 2001. Jurnal Uswah ini terbit dalam 12 halaman dengan ukuran A4. Sebagai Pimred, Sri Handayani menginginkan Bulletin Uswah Pusdai Jabar juga menurunkan liputan- 
liputan khusus yang diterbitkan selama tiga bulan sekali. Liputan jurnal Uswah pertama ini terbit dengan mengambil tema tentang koperasi. Sebagai narasumber ahli adalah Prof. Dr. Juhaya S. Praja, sebagai penggiat Koperasi Pesantren di Jawa barat.

Bulletin Uswah Pusdai Jabar edisi jurnal ini sempat menjadi kebanggan pada saat itu dan disebar ke beberapa rekanan Pusdai Jabar sekaligus orang-orang khusus seperti tokoh agama dan Ormas Islam seJawa Barat. Kendati dicetak dengan jumlah terbatas, namun jurnal Uswah tetap menjadi kebanggaan.

Sayangnya, jurnal Uswah hanya terbit satu kali terbitan. Keterbatasan anggaran menjadi kendala untuk menerbitkan di edisi selanjutnya. Padahal respon terhadap jurnal Uswah cukup positif dan meminta untuk dilanjutkan. Namun dengan alasan dana tadi, jurnal Uswa tidak pernah terbit kembali.

Pada fase pergantian kepengurusan, tahun 2004 Bulletin Uswah Pusdai Jabar berganti kepengurusan. Perubahan nama bidang dari Pengembangan Informasi (PI) menjadi Kajian Informasi dan Kemasyarakatan (KIK), menyebabkan personil berubah total. Secara otomatis keberadaan personil berimbas pada struktur redaksi Bulletin Uswah Pusdai Jabar.

Sejak tahun itu, Bulletin Uswah Pusdai Jabar kemudian dipegang langsung oleh ASM. Romli. Sejak saat itu pula keberadaan wajah Bulletin Uswah Pusdai Jabar menjadi berubah, sedikit dinamis. Jumlah rubrik bertambah kendatu halaman dan ukuran tetap. Namun dengan keterampilan design dan mengolah konten, ruang yang sempit bisa lebih dinamis dan enak dipandang.

Sejak saat itu, Bulletin Uswah Pusdai Jabar mengalami penambahan oplah karena permintaan dari beberapa mesjid yang ada di sekitar Pusdai Jabar. Kemudian pada periode ini juga Bulletin Uswah Pusdai Jabar mulai membuka layanan iklan baik display maupun iklan baris. Keberadaan iklan ini menambah sisi profesionalisme di Bulletin Uswah Pusdai Jabar.

Sebagai bentuk pengembangan, Bulletin Uswah Pusdai Jabar juga pernah terbit menjadi edisi ekslusif pada dua kali bulan ramadhan. Bulletin Uswah Pusdai Jabar edisi ramadhan terbit dengan ukuran A4 dan jumlah halaman delapan. Edisi ini memberikan warna tersendiri karena dapat memuat konten yang lebih banyak, termasuk memuat berbagai aktivitas ramadhan Pusdai Jabar yang sangat pariatif. 
Kebijakan Redaksi Media Dakwah dalam Membangun ...

Namun lagi-lagi, Bulletin Uswah Pusdai Jabar edisi ramadhan hanya bertahan dua edisi. Pertimbangannya selain dana, juga masukan dari beberapa pihak yang lebih cenderung menerbitkan majalah atau buku khusus di bulan ramadhan, bukannya mengubah Bulletin Uswah Pusdai Jabar yang sudah baku dengan karakternya.

Selama perjalanannya itu, konten Bulletin Uswah Pusdai Jabar selalu konsisten pada karakter yang mirip, yaitu sekitar akhlak, ibadah dan hal-hal yang sifatnya umum. Sifatnya pencerahan dan penguatan spiritualitas. Konten-konten ini tentu cocok untuk karakter pembaca Bulletin Uswah Pusdai Jabar karenanya, semakin hari bulletin ini semakin berkembang.

Hinga akhir terbitnya (Januari 2012), Bulletin Uswah Pusdai Jabar terbit sebanyak 4000 eksemplar (delapan rim). Iklan yang masuk sangat banyak bahkan mengantri untuk berebut halaman belakang. Bulletin Uswah Pusdai Jabar yang banyak itu disebarkan ke 23 mesjid di Kota Bandung dan Kabupaten Bandung. Bahkan sampai ke Majalaya. Namun setelah Pusdai Jabar benar-benar diambil alih oleh Pemprov Jawa Barat, dengan Ahmad Heryawan sebagai Gubernurnya, Bulletin Uswah Pusdai Jabar yang sangat popular itu kemudian diberhentikan tanpa alasan yang jelas.

\section{Kebijakan Redaktur Uswah Pusdai Jabar}

Dalam mengerjakan bulletin Uswah Pusdai Jabar, biasanya dilakukan secara mandiri tanpa intervensi dari pihak lain. Sebenarnya di atas penanggungjawab bulletin Uswah Pusdai Jabar ada ketua bidang, pada awalnya yaitu Kepala Bidang Pengembangan Informasi, kemudian berubah bidang menjadi Kepala Bidang Kajian, Informasi dan Kemasyarakatan (KIK). Namun demikian, dalam proses kerjanya, redaktur bulletin Uswah Pusdai Jabar tidak melibatkan pimpinan di atasnya.

Sebaliknya, pimpinan di atasnya tidak melakukan intervensi apapun terhadap pengelolaan bulletin Uswah Pusdai Jabar. Pernah kepala Bidang turut ikut campur pada awal tahun 2004, tetapi bukan dalam konteks isi tetapi lebih kepada kualitas cetakan dan waktu cetak yang lambat. Namun dalam hal isi, tetap mempercayakan kepada Pimred bulletin Uswah Pusdai Jabar.

Dari sisi struktur, untuk kasus di Pusdai Jabar, sesungguhnya pengurus DKM dalam arti yang mengurus ibadah ritual di ruang mesjid utama, sesungguhnya berada di bidang yang berbeda. Bidang yang

Ilmu Dakwah: Academic Journal for Homiletic Studies, Vol. 10 No.1 | Jan-Juni 2016247 
mengurus mejid dan aktivitas ritualnya adalah Bidang Pengembangan Ibadah dan Haji (PIH). Bidang inilah yang senantiasa mengelola aktivitas ritual dan aktivitas pengajian di ruang mesjid utama Pusdai Jabar.

Namun untuk kasus bulletin Uswah Pusdai Jabar, keberadaannya tidak memiliki struktur langsung dengan bidang PIH ini. Walaupun memang berada dalam satu manajemen Pusdai Jabar, namun Kepala Bidang PIH seolah-olah tidak ada struktur langsung, sehingga konsekwensinya adalah tidak bisa melakukan intervensi apapun terhadap bulletin Uswah Pusdai Jabar.

Karena tidak ada intervensi dari pihak manapun, maka pengelola bulletin Uswah Pusdai Jabar dapat melakukan semuanya dengan "bebas", mulai dari penentuan tema, modivikasi rubrikasi, lau out, oplah, sirkulasi, hingga marketing atau kebijakan tentang iklan.

Karena memiliki kewenangan penuh, pengelola bulletin Uswah Pusdai Jabar juga dengan kebebasan berekspresinya melakukan beberapa kali modivikasi dari sisi rubrikasi dan lay out. Beberapa kali perubahan itu dimaksudkan untuk mencari bentuk yang lebih dinamis dan enak dipandang. Karena, pengelola sadar betul bahwa persoalan media (walaupun kecil) tampilan tetap penting agar pembaca dapat menikmatinya.

Dari sisi jumlah, sebagaimana media pada umumnya, bulletin Uswah Pusdai Jabar redaksinya terdiri dari beberapa orang yang menempati posisi-posisi tertentu. Struktur keredaksian yang ada di alam bulletin Uswah Pusdai Jabar di antaranya Penanggungjawab, Dewan Redaksi, Pimpinan Redaksi, Redaktur Pelaksana, Lay out, Sirkulasi dan Iklan.

Namun, dalam manajemen bulletin Uswah Pusdai Jabar, struktur yang gemuk itu seringkali tidak efektif. Siapa yang mengerjakan dan menentukan semua, akhirnya diserahkan kepada Pimred. Dari merencanakan, menyediakan konten, hingga lay out, Pimred lah yang mengerjakan. Walaupun pada awalnya, struktur yang lain turut partisipasi seperti Redpel, namun akhirnya dikerjakan sendiri. Namun hal ini tidak mengurangi makna media, karena mungkin bulletin Uswah Pusdai Jabar ang hanya kecil saja sehingga tetap bisa dikerjakan.

Namun di samping itu ada juga sirkulasi dan percetakan. Mungkin dari semua pekerjaan, hanya dua hal inilah yang dikerjalan pihak lain, yaitu orang luar. Walaupun demikian, koordinasi secara tidak langsung tetap terbangun dengan adanya komunikasi antar anggota. 
Begitu dominannya pengelolaan bulletin Jum'at di Pusdai Jabar yang bertumpu kepada satu orang, sedikit banyak hal ini memberikan warna kepada isi bulletin sendiri. Karenanya, konten yang ada di dalam bulletin Uswah Pusdai Jabar sangat identik dengan pengelolanya. Karakteristik ini tidak hanya pada konteks selera dalam tata letak, warna dan rubrikasi, tetapi juga dalam membawa arah konten atau tema utama dalam bulletin Uswah Pusdai Jabar.

Sesungguhnya, pantas dihawatirkan bahwa akan ada bias kebijakan dari misi utama mesjid Pusdai Jabar. Hal ini diakibatkan dominannya individu dalam pengelolaan bulletin bulletin Uswah Pusdai Jabar. Namun ini juga bisa menjadi objektif ketika secara personal, pengelola bulletin Uswah Pusdai Jabar justru sangat paham dan tetap konsisten dalam mengemban misi utama mejid Pusdai Jabar.

Namun apa yang dilakukan oleh pengelola bulletin Uswah Pusdai Jabar dengan dominasi pengelolaan oleh satu orang, pada dasarnya bukan keinginan peribadi. Kondisi ini merupakan akibat dari adanya reposisi struktur mesjid atau Pusdai Jabar secara umum.

Dari beberapa orang yang tercantum dalam jajaran boks bulletin Uswah Pusdai Jabar, kemudian menjadi tidak aktif karena beberapa alasan, seperti ada yang keluar dari Pusdai Jabar. Ada juga yang pindah posisi ke bidang lain, sehingga tidak lagi secara langsung punya kaitan dengan pengelolaan bulletin Uswah Pusdai Jabar, walaupun mereka masih satu atap yaitu Pusdai Jabar. Namun ada juga yang tidak terlibat dalam pengelolaan bulletin Uswah Pusdai Jabar karena merasa punya pegangan program sendiri. Selain itu ada juga yang kurang peduli sehingga tidak mau terlibat.

Namun ketidak aktifan beberapa personil di boks redaksi tidak pernah dipersoalkan. Karena yang menjadi motor penggerak bulletin tidak berubah, maka bulletin tetap terbit dan seolah-olah tidak ada persoalan apapun di pengelola. Tidak pernah dilakukan pergantian atu restrukturisasi. Boks redaksi dibiarkan seperti semula, kendati yang ngelola tinggal sendiri.

Untuk memenuhi konten bulletin Uswah Pusdai Jabar, pada dasarnya dapat dilakukan sendiri, namun dalam beberapa hal diperlukan kerjasama dari bidang-bidang lain. Karena bulletin Uswah Pusdai Jabar juga diharapkan menjadi "corong" buat semua bidang yang ada di Pusdai Jabar, maka seluruh kegiatan dapat terekspose paling tidak info kegiatannya. Karenanya, secara aktif pihak redaksi harus menanyakan agenda kegiatan di berbagai bidang. Secara teknis kemudian beberapa 
bidang harus melakukan komunikasi dengan pengelola bulletin Uswah Pusdai Jabar agar dapat mengisi konten informasi.

Selain itu, di bulletin Uswah Pusdai Jabar juga ada rubrik pavorit bagi jamaah dan pasti membutuhkan partisipasi bidang lain atau Ustad di Pusdai Jabar. Rubrik itu adalah konsultasi. Rubrik ini menjadi ciri khas dari bulletin Uswah Pusdai Jabar dan banyak sekali peminatnya.

Rubrik konsultasi di bulletin Uswah Pusdai Jabar diperuntukan bagi jamaah yang memiliki berbagai persoalan, mulai dari keluarga, ibadah, akhlak, fiqih, muamalah, dan lain sebagainya. Semua konsultasi ini akan dijawab secara singkat oleh Ustad yang ada di Pusdai.

Pengelolaan rubrik ini pun ternyata tidak sederhana. Sebab pada dasarnya setiap penanya ingin cepat ada jawaban dan ingin memuaskan. Maka secara teknis ketika Ustad selalu stanby di Pusdai tentu tidak menjadi persoalan, namun ketika kendala jarak dan waktu maka pengelola bulletin Uswah Pusdai Jabar akan improvisasi karena kebetulan untuk beberapa hal yang ditanyakan pengelola bulletin Uswah Pusdai Jabar juga bisa menghendelnya.

Jadi secara umum, pengelolaan bulletin Uswah Pusdai Jabar lebih banya dilakukan seorang diri. Jika ada nilai atau muatan yang masuk pada bulletin Uswah Pusdai Jabar maka lebih banyak dari satu orang tersebut yang selalu mengelola bulletin. Walaupun demikian, secara umum, proses pengelolaan tidak terlalu menjadi masalah sebab dari sisi "warna" bulletin tidak berubah.

\section{Konten Bulletin Uswah Pusdai Jabar}

Bulletin Uswah Pusdai Jabar sejak awal memiliki corak yang terbuka. Sebagaimana halnya Pusdai Jabar yang posisinya sebagai lembaga milik ummat, inklusif, tidak berpihak dan condong kepada idiologi tertentu atau Ormas Islam tertentu, Pusdai Jabar tentu berada di atas itu semua. Kondisi ini yang kemudian dicerminkan oleh bulletin Uswah Pusdai Jabar.

Visi bulletin Uswah Pusdai Jabar sebenarnya tidak keluar dari visi Pusdai Jabar sendiri. Pusdai Jabar dari aspek namanya saja sudah memberikan informasi yang jelas, yaitu sebagai pusat dakwah Islam di Jawa Barat. Dakwah di sini bersifat umum, artinya paling tidak dapat mengandung dua hal, pertama, Pusdai Jabar harus menjadi "tenda" untuk semua aliran Islam yang ada di Jawa Barat. Karenanya tidak ada yang berhak mendominasi atau menguasai Pusdai Jabar.

250 Ilmu Dakwah: Academic Journal for Homiletic Studies, Vol. 10 No.1 | Jan-Juni 2016 
Kedua, Pusdai Jabar melaksanakan aktivitas keislaman, baik yang bersifat ritual, sosial dan berbagai aktivitas kebaikan lainnya. Karenanya, Pusdai Jabar dalam melakukan dakwahnya melakukan dua cara yaitu berdasarkan program yang direncanakan dan dibuat oleh Pusdai Jabar sendiri, juga program atau kegiatan yang dilakukan oleh pihak luar, baik itu pihak Ormas, komunitas, kampus, dan sebagainya.

Sebagai pusat dakwah, Pusdai Jabar tidak melihat dan membatasi siapapun untuk melakukan dakwah apapun di Pusdai Jabar, selama hal itu dalam konteks kebaikan. Inklusifisme Pusdai Jabar dalam membuka ruang dakwah bagi masyarakat, membuat Pusdai Jabar sebenarnya tidak menunjukkan corak aliran tertentu, tetapi semua pihak dapat terayomi. Walaupun secara umum, masyarakat menilai bahwa Pusdai Jabar merupakan lembaga dakwah bercorak moderat.

Visi inilah yang kemudian menjadi bagian dari bulletin Uswah Pusdai Jabar. Corak bulletin Uswah Pusdai Jabar mencerminkan kedamaian dan hal-hal kebaikan lainnya. Pengelola bulletin sadar betul bahwa kehadiran media di lembaga dakwah seperti Pusdai pasti harus menjadi media yang inklusif, moderat dan lebih menghindari hal-hal yang bersifat fikhiyah.

Namun, selain pesan-pesan dakwah, bulletin Uswah Pusdai Jabar juga berfungsi untuk melakukan informasi berbagai kegiatan yang dilakukan oleh Pusdai Jabar. Informasi yang disampaikan lebih kepada info rencana kegiatannya, bukan berita dari kegiatan tersebut. Sebab selain ukuran bulletin yang kecil, juga karakteristik dari bulletin Uswah Pusdai Jabar memang bukan untuk berita (news) tetapi lebih kepada opini (views) dan konsultasi.

Informasi kegiatan juga tentu merupakan bagian dari aktivitas dakwah yang dilakukan oleh Pusdai Jabar. Jadi di sini ada sinergi antara dakwah secara tertulis yang langsung dimuat di bulletin Uswah Pusdai Jabar dengan informasi kegiatan yang merupakan info kegiatan dakwah yang dilakukan oleh Pusdai Jabar.

Secara teknis juga, informasi kegiatan ini tidak hanya dilakukan di bulletin Uswah Pusdai Jabar tetapi juga disebarluarkan lagi lewat pengeras suara sebelum Jum'atan dimulai di Mesjid Pusdai Jabar. Walaupun petugasnya bukan dari pengelola bulletin Uswah Pusdai Jabar, namun apa yang disampaikan merupakan penegasan dari informasi yang hanya tertulis. Petugas DKM hanya membacakan dari apa yang tertulis di bulletin Uswah Pusdai Jabar. Hal ini dimaksudkan bagi para jamaah yang tidak kebagian bulletin Uswah Pusdai Jabar karena keterbatasan cetakan. 
Karena pada dasarnya, keberadaan bulletin Uswah Pusdai Jabar yang disebarkan di jamaah Jum'at di Pusdai sendiri mungkin kurang dari setengahnya dari total jamaah yang bisa mencapai empat ribu orang setiap minggunya.

Sebelum akhirnya bulletin Uswah Pusdai Jabar di berhentikan oleh Satgas Pusdai Jabar yang terdiri dari para pejabat dari Pemerintahan Provinsi Jawa Barat pada bulan Februari 2012, pengelola terakhir bulletin Uswah Pusdai Jabar ini mengakui bahwa keberadaannya tetap konsisten pada prinsip dan visi-misi utamanya.

Menurutnya, bulletin Uswah Pusdai Jabar menjadi yang paling depan dalam membackup visi-misi Pusdai Jabar yaitu sebagai pusat dakwah di Jawa Barat. Dengan corak moderat dan berdiri di atas semua golongan, bulletin Uswah Pusdai Jabar menyajikan konten-konten yang berorientasi pada tercapainya visi-misi Pusdai Jabar. Karena coraknya seperti itu, maka sampai tulisan ini dibuat, bulletin Uswah Pusdai Jabar dianggap sebagai bulletin Jum'at paling besar oplahnya yang dibuat dan dikelola oleh mesjid di Jawa Barat, sekurang-kurangnya Bandung Raya.

Hal ini terlihat dari jumlah eksemplar yang bisa mencapai empat ribu setiap minggunya, dengan tingkat penyebaran ingga mencapai Majalaya-Kabupaten Bandung. Padahal pengelolanya mengaku, tidak ada promosi yang dilakukan agar bulletin Uswah Pusdai Jabar bisa masuk ke mesjid-mesjid sebanyak 23 mesjid di Jabar ini.

Karena penyebarannya yang begitu massif, mungkin pihak lain pun melirik bulletin Uswah Pusdai Jabar ini. Akhirnya, sangat tidak aneh jika kemudian bulletin Uswah Pusdai Jabar banyak iklan yang masuk. Pengelola sendiri mengakui seringkali mengantri, sebab tidak mungkin halaman cuma empat, kemudian menghabiskan setengah dua halaman untuk iklan tentu tidak etis. Sebab misi utama bulletin Uswah Pusdai Jabar adalah dakwah, bukan mencari keuntungan.

Yang paling mengesankan, ketika iklan bulletin juga masuk pada wilayah "kuping". Iklan kuping yang biasanya hanya kita temuka di media-media besar, namun untuk bulletin Uswah Pusdai Jabar seringkali dilakukan. Kendati harga iklan di sini lebih mahal, padahal ukurannya lebih kecil - karena hanya terletak di pinggir kiri atau kanan tulisan nama buetin "Uswah" di halaman depan atas - namun beberapa kali berbagai lembaga menginginkan space itu.

Yang tidak kalah pentingnya yaitu iklan banner bawah. Walaupun di berbagai bulletin sangat jarang ditemukan, kita sering menemukannya 
di bulletin Uswah Pusdai Jabar. Walaupun akhirnya ditiadakan, dengan alasan mengurangi konten utama, namun keberadaannya peminat untuk mengisi iklan banner bawah dan atas merupakan bentuk kepercayaan mereka terhadap bulletin Uswah Pusdai Jabar.

Apa yang dilakukan pengelola bulletin Uswah Pusdai Jabar dengan memasukan iklan merupakan bentuk pembuktian bahwa bulletin Uswah Pusdai Jabar sangat eksis dan dipercaya banyak orang. Karenanya, pemuatan iklan dilakukan, namun pembatasan juga diperketat.

Semua kepercayaan dan apresiasi jamaah termasuk para pengiklan, dalam pandangan pengelola merupakan bentuk feed back dari apa yang disampaikan oleh bulletin Uswah Pusdai Jabar tentang pesan-pesan dakwah yang mungkin dapat diterima masyarakat secara luas. Sebab tidak mungkin banyak permintaan dan orang memasang iklan jika pesan dakwahnya tidak dapat diterima oleh masyarakat.

Secara konteks dakwah yang kemudian berkembang di bulletin Uswah Pusdai Jabar adalah keberadaan rubrik konsultasi. Rubrik ini hanya setangahh halaman, tetapi sangat banyak peminatnya. Jumlah yang konsultasi dalam seminggunya bisa sampai puluhan. Padahal rubrik ini hanya memuat empat sampai lima jawaban atas pertanyaan saja. Terlebih jika ada pertanyaan yang tidak bisa dijawab secara singkat, maka jumlahnya akan semakin sedikit.

Karenanya, redaksi semaksimal mungkin melakukan editing terhadap jawaban dari Ustad yang disampaikan. Sebab penghematan kata juga bagian dari layanan kepada masyarakat agar lebih banyak yang terjawab. Karenanya, walaupun singkat-singkat, dipastikan bahwa jawaban itu cukup komunikatif untuk menjawab apa yang dipertanyatakan.

Apa yang dilakukan bulletin Uswah Pusdai Jabar dengan rubrik konsultasi ini, merupakan bentuk dakwah yang sangat penting. Sebab ternyata persoalan dakwah bukan hanya menyampaikan pesan, tetapi juga menjawab berbagai persoalan yang tersebar di kalangan masyarakat.

Dari sekian banyak konsultasi yang dilakukan, kebanyakan dari mereka yaitu seputar masalah ibadah, keluarga, khilafiah, akhlak, dan halhal yang sifatnya peribadi. Pada dasarnya setiap penanya ingin diprioritaskan untuk dijawab, Karena tidak sedikit juga persoalan yang dialaminya sangat mendesa.

Atas perkembangan dan animo masyarakat khususnya di bidang konsultasi ini, kemudian pengelola bulletin Uswah Pusdai Jabar membuka layanan konsultasinya via online. Dengan cara ini maka 
persoalan yang disampaikan tidak perlu menunggu satu minggu pada waktu bulletin terbit. Jadi dalam hitungan hari, bahkan hitungan jam, persoalan itu sudah bisa dijawab oleh pengelola atau pihak Pusdai Jabar.

Sayangnya, tidak semua yang konsultasi itu tahu bahwa sebenarnya yang mengelola bulletin atau admin via online itu adalah Ustadnya sendiri, sehingga banyak yang tidak sabaran ketika mereka bertanya. Padahal pada dasarnya ada beberapa pertanyaan yang sesungguhnya harus dikonfirmasikan kepada Ustad yang memberikan pertanyaan dan itu perlu waktu.

Namun demikian, fungsi media yang sangat efektif, kemudian rubrik ini tetap menjadi sangat diminati, dan dikelola dengan dua versi yaitu versi cetak dan versi online. Keduanya bersinergi, bagi yang sangat mendesak akan dijawab via online, namun yang tidak terlalu mendesak akan dijawab di versi cetak.

Dari sisi penyajian, rubrik konsultasi ini dibuat semacam head line (HL), sebagaimana halnya berita biasa yang selalu ada prioritas bagi berita yang sekiranya dianggap paling penting. Dengan penulisan judul lebih besar dan disimpan paling atas, inilah cara memposisikan konsultasi yang dianggapnya lebih penting.

Selain itu, penyajian konsultasi dilakukan secara acak, tidak satu tema, tetapi beberapa tema sekaligus. Kalau ada empat konsultasi yang dimasukan, maka disitu ada empat tema yang dibahas. Begitulah seterusnya. Yang jelas, rubrik ini dapat mewakili jamaah yang memiliki kemiripan pertanyaan dengan yang telah dijawab.

Apa yang menjadi konten dalam rubrik konsultasipun pada dasarnya tidak keluar dari visi-misi bulletin Uswah Pusdai Jabar yaitu sebagai penyangga visi-misi Pusdai Jabar sebagai pusat dakwah ummat Islam di Jawa Barat. Karenanya, corak konsultasi diharapkan dapat lebih inklusif terutama dalam memberikan jawaban-jawaban, agar tidak terkesan menggiring ke sebuah pemahaman mazhab tertentu.

Kendati demikian, sebagai manusia biasa, baik Ustadz maupun pengelola bulletin Uswah Pusdai Jabar, tentu saja memiliki subjektifitas yang tidak bisa dilepaskan dari setiap jawaban yang diberikat. Terlebih jika jawaban itu sudah masuk pada improvisasi, maka di sinilah subjektivitas itu masuk. Walaupun mungkin kadarnya sedikit, sehingga tetap dalam kolidor bulletin Uswah Pusdai Jabar yang berfungsi untuk menjadi "tenda" bagi semua. 
Kebijakan Redaksi Media Dakwab dalam Membangun ...

Sedangkan dari sisi tema bulletin Uswah Pusdai Jabar yang biasanya diangkat adalah hal-hal yang ada kaitannya dengan hari besar Islam, tema dakwah secara umum, tentang ibadah, dan ukhuwah. Tematema ini diharapkan dapat mencerminkan bulletin Uswah Pusdai Jabar sebagai bulletin milik ummat dan dapat melakukan syiar tentang Islam.

Tema-tema tersebut dikemas dalam berbagai tulisan yang terkadang dalam bentuk narasi opini biasa, ada juga yang dikemas dalam bentuk ceritera atau ilustrasi. Penyajian sendiri tidak dibatasi pada jenis tulisan atau karakter tertentu, asal jenis kategori opini (views), pengelola memberi kebebasan. Yang paling penting dari tulisan-tulisan yang ada di dalamnya adalah efektifitas penyampaian pesan kepada masyarakat.

Tema-tema di atas tidak diturunkan secara periodik, atau memiliki jadwal yang khusus, melainkan mengalir tergantung pada kondisi dimana situasi dan kondisi ketika naskah itu dibuat. Bisa jadi beberapa minggu hanya mengangkat tema ibadah, bisa juga beberapa minggu tentang ukhuwwah, atau bisa jadi selalu diselang dengan tema-tema yang variatif.

Apa yang menjadi tema-tema setiap minggunya di bulletin Uswah Pusdai Jabar, sangat bergantung pada kepentingan dakwah dengan memperhatikan tema-tema di atas. Karenanya, konten bulletin Uswah Pusdai Jabar tidak ditentukan oleh peristiwa aktual tetapi lebih kepada kepentingan pesan. Walaupun tidak ada kaitannya dengan sebuah peristiwa aktual, namun dikira penting disampaikan, maka sebuah tulisan akan dibuat tanpa memperhatikan sebuah peristiwa aktual.

Namun demikian, bukan berarti sisi aktualitas tidak penting, selama pesan itu relevan dengan beberapa kriteria tulisan bulletin Uswah Pusdai Jabar maka akan diangkat. Karenanya, pemberian pemahaman bagi pengelola bulletin Uswah Pusdai Jabar menjadi sangat penting, dengan memperhatian beberapa tema di atas.

Aspek aktualitas misalnya akan menjadi penting ketika sudah bertemua dengan salah satu criteria di atas. Contohnya ketika pada minggu tertentu ada hari besar Islam. Pada saat itulah pengelola bulletin Uswah Pusdai Jabar akan menurunkan tema yang sesuai dengan hari besar Islam yang jatuh pada minggu tersebut. Baik hari besar Islam itu jatuh di hari Jum'at, atau sebelum dan sesudahnya, tidak menjadi soal. Sebab dalam aktualita versi bulletin Uswah Pusdai Jabar adalah dimana situasi minggu itu sedang berada dalam nuansa hari besar Islam tersebut. Jadi aktualitas tidak selamanya berada di hari dimana konten itu dibuat atau dimana bulletin itu terbit.

Ilmu Dakwah: Academic Journal for Homiletic Studies, Vol. 10 No.1 | Jan-Juni 2016 
Dalam pengangkatan tema setiap minggunya, bulletin Uswah Pusdai Jabar sebenarnya tidak memiliki jadwal khusus. Sebab pada dasarnya tulisan itu disesuaikan dengan perkembangan isu yang muncul di masyarakat. Selain itu, terkadang keberadaan tema yang diangkat juga sangat tergantung pada kesediaan naskah. Sebab dalam konteks bulletin, tidak banyak orang yang tertarik menulis secara rutin. Sehingga keberadaan naskah ini sangat mempengaruhi juga tema-tema yang diangkat di bulletin Uswah Pusdai Jabar.

Tidak sedikit juga, tema-tema yang terkait dengan hari-hari besar Islam, kemudian harus mendaur ulang dari tulisan yang sama di tahun sebelumnya. Sebab pada dasarnya, tulisan hari-hari besar itu bersifat aktual dari sisi penanggalan. Artinya, tanggal itu akan kembali datang di tahun yang sama. Sehingga pesan dan temanya akan sangat mirip. Yang dilakukan pengelola bulletin adalah melakukan improvisasi atau modivikasi, baik dari sisi judul, maupun tata letak tulisan. Bisa juga modivikasi tersebut dilakukan berdasarkan pada peristiwa actual yang terjadi pada tahun ini. Sehingga bisa jadi pada pengantar atau contoh kasusnya menjadi berbeda.

Intinya, bulletin Uswah Pusdai Jabar pada dasarnya menginginkan sampainya pemahaman yang baik dan benar tentang Islam dan kaum muslimin. Sebaliknya, pesan bulletin Uswah Pusdai Jabar juga menginginkan agar umat Islam terbebas dari berbagai praktik ibadah yang salah atau tidak sesuai dengan sunnat Rasulullah.

Pengelola bulletin Uswah Pusdai Jabar menginginkan agar ummat Islam, terutama para pembaca bulletin Uswah Pusdai Jabar akan mendapatkan pemahaman yang baik danbenar tentang Islam. Baik pada aspek ibadah, muamalah dan akhlak, bulletin Uswah Pusdai Jabar menginginkan agar ummat Islam senantiasa mengacu kepada dua hal yaitu al-Quran dan sunnah Rasulullah.

Segala bentuk peribadatan yang keluar kolidor itu, maka pengelola bulletin Uswah Pusdai Jabar ini menganggap sebagai bentuk ketidak pahaman ummat terhadap ajaran Islam yang sebenarnya. Karenanya, konten bulletin Uswah Pusdai Jabar akan selalu mengacu kepada alQuran dan sunnat, tanpa menggiring pada mazhab-azhabt tertentu. Walaupun tentu saja bukan berarti menafikan keberadaan ulama-ulama besar pada zaman dahulu.

Oleh karena itu, sebaliknya dari criteria di atas adalah bagaimana bulletin Uswah Pusdai Jabar menurut pengelolanya dapat menghindar 
tiga hal penting, pertama, menghindari bid'ah, khurafat dan yahayul. Kedua, menghindari dari penggiringan pada isu khilafah. Ketiga, membebaskan dari isu dan kepentingan politik praktis.

Dalam konteks bid'ah, khurafat, dan tahayul, pengelola bulletin Uswah Pusdai Jabar bermaksud untuk membebaskan keimanan dan tauhid ummat Islam dari hal-hal yang dapat menjerumuskannya. Begi pengelola bulletin Uswah Pusdai Jabar, sifat-sifat tersebut dianggap akan mengganggu aqidah ummat Islam sehingga menyelewengkan segala bentuk peribadatan, yang seharusnya bersumber pada pada sumber Islam tetapi malah melenceng.

Sebagai bulletin yang berada di lembaga dakwah modern, pengelola bulletin Uswah Pusdai Jabar berharap, dengan medianya yang kecil itu, namun dapat memberikan pemahaman tentang Islam yang benar sehingga tidak terjebak pada peribadatan atau perilaku yang menyimpang dari dua pegangan ummat Islam yaitu al-Quran dan sunnah Rasul.

Dalam konteks khilafah, pengelola bulletin Uswah Pusdai Jabar menganggap hal itu merupakan wacana yang tidak perlu dikembangkan. Islam dalam pandangan pengelola bulletin Uswah Pusdai Jabar bersifat substantive, sehingga apa yang dilakukan dengan dakwah dan perilaku Islami, yaitu include dalam perilaku keseharian, tidak perlu diformalisasi menjadi sebuah Negara Islam, apalagi berada di dalam sebuah khilafah.

Sedangkan politik praktis, bagi pengelola bulletin Uswah Pusdai Jabar hal ini hanya akan menjebak ummat. Karenanya bulletin Uswah Pusdai Jabar diupayakan selalu steril dari kepentingan politik. Politik dalam pandangan pengelola bulletin Uswah Pusdai Jabar merupakan ladang dakwah, namun jika melihat dari aspek praktis, politik hari ini cenderung negatif, penuh ketidakjujuran, serba menipun dan lain-lain.

Karenanya, dalam kepentingan untuk menjaga keberpihakan bulletin Uswah Pusdai Jabar dari berbagai kepentingan politik praktis, konten bulletin Uswah Pusdai Jabar selalu dijaga agar tidak menyinggung hal itu. Walaupun demikian, sesekali bulletin Uswah Pusdai Jabar juga memberikan pendidikan politik, namun bersifat adiluhung, konseptual dan sesuai dengan politik Islam yang agung. Sedangan pada aspek politik praktis yang senantiasa dijalani di Negara kita, bulletin Uswah Pusdai Jabar tidak melakukan pengarahan dan tidak menurunkan tema khusus.

Kendati sangat jelas di lapangan ummat menemukan partai politik Islam, namun dalam pandangan pengelola bulletin Uswah Pusdai Jabar, 
pada dasarnya sama saja. Kemudian, yang perlu disadari juga bahwa keberadaan ummat yang menjadi konsumen bulletin Uswah Pusdai Jabar sangat beragam sehingga tidak mungkin dilakukan pengarahan kepada kepentingan politik tertentu.

Untuk menjaga konten bulletin Uswah Pusdai Jabar, pengelola cukup ketat dalam mengambil sumber tulisan. Tulisan, khususnya tema utama biasanya dibuat oleh tim redaksi, walaupun kebanyakan oleh satu orang yaitu pengelola bulletin Uswah Pusdai Jabar itu sendiri. Selain itu tulisan juga diambil dari hasil ceramah dhuha yang selalu dilakukan di Pusdai Jabar. Ceramah dhuha merupakan kegiatan pengajian yang dilaksanakan secara rutin oleh Pusdai Jabar pada hari Minggu pagi. Pada pengisi di ceramah dhuha merupakan Ustad pilihan setelah melakukan seleksi dari aspek kemampuan dan pemahaman yang baik terhadap Islam. Dengan demikian ketika hasil ceramahnya diambil oleh bulletin Uswah Pusdai Jabar, maka tulisan tersebut sangat bagus dan berbobot.

Selain itu, tulisan juga berasal dari pada Ustad yang ada di Pusdai Jabar. Kendati demikian, tulisan dari ustad ini tidak rutin karena kesibukan dan kemampuan menulis yang baik. Maka alternatifnya tetap kembali ke pengelola lagi. Jika stok tulisan ini habis, maka pengelola akan "melirik" internet, sebagai sumber tulisan, dengan pemilihan pada aspek konten dan siapa penulisnya. Jadi dari manapun tulisan itu, tetap aspek kriteria dilakukan dengan ketat.

Semua pesan-pesan dakwah yang bersifat mencerahkan di bulletin Uswah Pusdai Jabar itu oleh pengelolanya dituangkan dalam beberapa rubrik yang disediakan, seperti artikel utama, lintas dunia Islam, konsultasi singkat islam, mutiara hadits, dan mitra Uswah (Islam). Kesemuanya dilakukan dalam rangka mendukung visi-misi Pusdai Jabar sebagai lembaga dakwah terkemuka di Jawa Barat yang dapat mengayomi seluruh ummat.

\section{Bulletin Gema Mujahidin}

Sejauh penelusuran, tidak ada yang tahu kapan bulletin Gema Mujahidin mulai terbit. Yang jelas, sejak tahun 1995, bulletin Gema Mujahidin sudah berjalan dan banyak dikenal jamaah Mesjid Mujahidin. Dengan demikian, diasumsikan bulletin ini sudah mulai terbit tahun 1990-an di masa awal-awal beroperasinya Mesjid Raya Mujahidin.

Hingga tahun 1995, bulletin Gema Mujahidin dikelola oleh Mesjid Raya Mujahidin. Alasannya tentu sesuai dengan keberadaan bulletin ini 
yang memang berada di Mesjid Raya Mujahidin dan diterbitkan setiap hari Jum'at. Terbitan ini sejak awal diperuntukan bagi jamaah shaat Jum'at yang jumlahnya mencapai ribuan orang.

Namun, entah mengapa, sejak tahun 1995, bulletin Gema Mujahidin tidak dikelola oleh mejid, melainkan oleh Pimpinan Wilayah Muhammadiyah Jawa Barat. Dalam teknisnya, pengelolaan ini diserahkan kepada Majelis Pustaka dan Informasi yang saat itu diketuai M. Rifadi.

Alasan yang beredar pada saat itu adalah perlunya memberdayakan Majelis Pustaka dan Informasi (MPI) PW Muhammadiyah Jabar. Karena belum ada garapan yang jelas, maka diberikan amanah untuk menggarap bulletin Gema Mujahidin. Sehingga pada saat itu, pengurus Mesjir Raya Mujahidin tidak memiliki lagi kewenangan untuk mengurus dan menentukan bulletin Gema Mujahidin.

Pada kepemimpinan PW Muhammadiyah Jabar oleh Hidayat Salim tersebut, MPI yang diketuai M. Rifadi ternyata tidak hanya mengelola bulletin Gema Mujahidin, tetapi juga memiliki percetakan sendiri. Karenanya proses cetak bulletin Gema Mujahidin tidak pernah ke luar, melainkan di percetakan yang dikelolanya sendiri, yang pada saat itu lokasinya ada di belakang kantor mesjid. Secara teknis, percetakan itu dioperasikan oleh anggota MPI lainnya yaitu Pak Iwan.

Sayangnya, M. Rifadi saat itu tidak lama menanggungjawabi bulletin Gema Mujahidin. Pengelolaan oleh M. Rifadi ini mungkin maksimal dua tahun. Selanjutnya, bulletin Gema Mujahidin ini dikelola oleh Pak Iwan. Jadi Pak Iwan selain mengoperasikan mesin cetak, juga mengelola bulletin Gema Mujahidin juga.

Yang disayangkan dari pengelolaan bulletin Gema Mujahidin oleh Pak Iwan ini adalah aspek kualitas isi. Diduga, pengelolaan bulletin tidak menjadi prioritas, karena yang pokok adalah mencetaknya. Karenanya, sumber tulisan menjadi tidak dikelola dengan baik. Kualitas itu dipertanyakan dari aspek isi dan penulisnya.

Puncak kekecewaan jamaah pada kualitas bulletin Gema Mujahidin adalah ketika adanya jamaah yang komplain terhadap isi bulletin Gema Mujahidin. Jamaah menilai penulis yang ada di bulletin Gema Mujahidin tidak layak karena orangnya sudah meninggal. Jadi mana mungkin orang yang sudah meninggal tetapi masih bisa menulis.

Menurunnya kualitas bulletin Gema Mujahidin ini kemudian menurunkan permintaan dari jamaah. Karenanya, lama kelamaan, bulletin Gema Mujahidin menurun tidak hanya dari isinya, tetapi juga dari sisi ukuran. Bulletin Gema Mujahidin yang sejak awal dicetak dalam 
ukuran A4 kemudian berubah menjadi A5. Mengecilnya ukuran bulletin Gema Mujahidin ini menunjukkan menurunnya kualitas bulletin yang diakibatkan oleh ketidak seriusan dalam pengelolaannya.

Pada saat itulah masa di mana bulletin Gema Mujahidin kehilangan ruhnya sebagai media dakwah yang memiliki idiologi yang jelas. Namun pada masa pengelolaan yang semakin menurun, diduga bulletin Gema Mujahidin kehilangan ruhnya. Identitas dan idealisme bulletin Gema Mujahidin menjadi hilang, sehingga jamaah merasa tidak mendapatkan sesuatu dari bulletin tersebut. Karenanya, para peminat bulletin Gema Mujahidin semakin hari semakin sedikit.

Untuk menghindari hal yang lebih merugi dari sisi kepentingan dakwah, akhirnya pada tahun 1998, bulletin Gema Mujahidin kembali diambil alih oleh pengurus Mesjid Raya Mujahidin. Walaupun tidak langsung dikelola oleh para pengurus mesjid secara sturktural, namun paling tidak kendali bulletin Gema Mujahidin ada di mesjid lagi, bukan di PW Muhammadiyah.

Pada tahun itu, bulletin Gema Mujahidin diserahkan oleh pengurus mesjid kepada Dikdik Dahlan. Dikdik pada saat itu merupakan aktivitas Ikatan Mahasiswa Muhammadiyah yang dianggap memiliki potensi untuk mengembangkan bulletin Gema Mujahidin.

Atas dasar kepercayaan itulah kemudian Dikdid mulai melakukan pembenahan dalam pengelolaan bulletin Gema Mujahidin. Kendatu bukan orang yang secara struktural merupakan pengurus Mesjid Raya Mujahidin, namun Dikdik diberi kepercayaan penuh untuk mengelola dan menentukan konten bulletin Gema Mujahidin.

Dalam proses penggarapan bulletin Gema Mujahidin ini, Dikdik melakukan pembenahan dari mulai tata letak (lay out), mengembalikan ukuran bulletin menjadi A4, menambah rubrik dari satu menjadi empat, hingga penyebaran dan pencarian sponsor. Terkait dengan dengan konten, rubrik bulletin Gema Mujahidin yang tadinya hanya opini utama, dikembangkan menjadi tulisan utama atau opini, kolom, info kegiatan (mimbar Mujahidin) dan sesekali memuat iklan.

Proses pengelolaan yang membaik membuat bulletin Gema Mujahidin kembali citranya. Selain ukuran yang berubah menjadi seperti semula, konten dan semakin dinamis dari sisi isi, jamaah seolah kembali menemukan kembali bulletin Gema Mujahidin yang sebenarnya.

Perkembangan dari hasil perbaikan pengelolaan bulletin Gema Mujahidin ini kemudian membuat penyebaran bulletin semakin massif. 
Kebijakan Redaksi Media Dakwah dalam Membangun ...

Tidak kurang dari 13 mesjid yang ada di Kota Bandung selalu berlangganan pada zaman Dikdik ini. Walaupun masing-masing mejid harus membayar setiap bulletin yang dipesannya, namun seolah-olah tidak keberatan, karena mungkin mereka puas dengan apa yang disajikan.

Periode pengelolaan bulletin Gema Mujahidin oleh Dikdik sebenarnya terpotong ketika di tengah perjalanan, Dikdik sendiri harus menjadi ketua Badan Ta'mir Mesjid Mujahidin. Jadi secara teknis pengelolaan bulletin Gema Mujahidin dipegang oleh Jejen sebagai pelaksana. Namun demikian, karena Dikdik sebelumnya mengurus bulletin Gema Mujahidin, maka ketika menjadi ketua BTM Mujdhidin pun Dikdik selalu turut memantau, walaupun secara teknis tidak melakukannya.

Masuk pada periode kepengurusan baru di PW Muhammadiyah Jabar, 2005 terjadi perubahan kepengurusan dan berimbas pada pengurus BTM Mujahidin. Secara otomatis, bulletin Gema Mujahidin kemudian ditangani oleh orang baru yang ditunjuk adalah Isa Nur Zaman.

Babak baru pengelolaan bulletin Gema Mujahidin ini memiliki corak yang sedikit beda kendati secara substansi tetap sama. Keberadaan ukuran bulletin tetap sama, namun dari sisi lay out dibuat lebih dinamis. Tema-tema yang diangkat sedikit berbeda, termasuk para penulisnya. Pola pendistribusian tetap sama dengan jumlah yang relative stabil.

Hingga penelitian ini dilakukan, bulletin Gema Mujahidin tetap eksis dan menjadi satu-satunya bulletin yang dimiliki dikelola oleh mesjid yang berada di bawah naungan Muhammadiyah di Jawa Barat yang cukup besar. Bisa jadi, media dakwah ini memberikan warna terhadap corak pemikiran jamaah baik di Mujahidin maupun jamaah di luar Mujahidin tetapi turut membaca bulletin Gema Mujahidin.

\section{Kebijakan Redaksi Bulletin Gema Mujahidin}

Bulletin Gema Mujahidin pada dasarnya berada di bawah manajemen BTM Mesjid Mujahidin. Sedangkan Mesjid Mujahidin sendiri berada di bawah PW Muhammadiyah Jawa Barat. Ini adalah struktur resmi dari dulu hingga sekarang. Karenanya dalam bulletin Gema Mujahidin selalu ada logo Muhammadiyah, walaupun hanya kecil, karena mempertimbangkan jamaah Mujahidin yang lebih beragam - bukan hanya warga Muhammadiyah.

Kendati demikian, pada faktanya, bulletin Gema Mujahidin sesungguhnya dikelola dan ditanggungjawabi oleh orang-orang tertentu yang dituntuk sebagai pelaksana. Pengurus BTM Mesjid Mujahidin,

IImu Dakwah: Academic Journal for Homiletic Studies, Vol. 10 No.1 | Jan-Juni 2016261 
apalagi PW Muhammadiyah Jawa Barat, hampir tidak tahu-menahi pengelolaan bulletin Gema Mujahidin ini.

Sejak masa awal, para pengelola bulletin Gema Mujahidin sudah diberi kewenangan penuh untuk menentukan berbagai halnya, baik fisiknya, konten hingga pendistribusiannya. Walaupun sempat ada perpindahan dari mesjid ke majelis di PW Muhammadiyah Jabar, namun sunstansi pengelola adalah mereka yang secara mandiri tidak diintervensi oleh pihak luar.

Bahkan hingga penelitian ini dilakukan, pola ini tetap berjalan, walaupun pengelolanya terus berganti-ganti. Di boks redaksi tetap banyak pihak terlibat, namun secara teknis hanya satu orang saja yang menentukan segalanya. Orang lain yang terlibat di sini hanya terbatas pada penyediaan konten untuk pengumuman kegiatan, atau mungkin membantu pengadaan naskah. Sedangkan finalnya tetap di orang yang mengelola itu.

Pada zaman Dikdik misalnya, untuk pengisi topik utama dibuat jadwal khusus. Mereka terdiri dari para pengurus Muhammadiyah Jabar, pengurus BTM Mesjid Mujahidin, tokoh-tokoh tertentu dan masyarakat umum. Mereka diberi kesempatan yang sama untuk mengisi topik utama bulletin Gema Mujahidin. Namun pada akhirnya tetap pengelola yang sendiri itu yang menentuka mana yang harus dimuat.

Kebijakan waktu itu adalah mementingkan substansi materi daripada melihat siapa yang menulis. Walaupun yang menulis tokoh Muhammadiyah, jika tidak memenuhi standard penulisa dan konten, maka tidak jarang pengelola lebih baik memuat tulisan dari luar, walaupun bukan pengurus Muhammadiyah, selama tulisannya dianggap lebih baik.

Cemin dari besarnya kewenangan pengelola bulletin Gema Mujahidin adalah ketika menentukan tulisan seperti di atas. Hal ini, bukan tidak sadar bahwa bulletin Gema Mujahidin berada di bawah naungan Muhammadiyah, tetapi pengelola lebih memperhatikan jamaah mesjid Mujahidin yang lebih plural. Walaupun tentu saja setiap materi juga sejalan dengan ajaran Muhammadiyah dan tidak keluar dari pedoman al-Islam yang diyakininya.

Termasuk dalam penentuan iklan, pengelola bulletin Gema Mujahidin tidak pernah koordinasi dan tidak mendapat teguran ketika memuat iklan dari luar. Yang menentukan apakah iklan itu diterima atau 
tidak, tidak tergantung kepada keputusan bersama, apalagi pengurus di atasnya, melainkan tergantung dari pengelolanya itu sendiri.

Selain itu, untuk penentuan konten bulletin Gema Mujahidin, sebagai mana media massa pada umumnya, sebaiknya dibahas lewat rapat redaksi, namun pada kenyataannya rapat redaksi bulletin biasanya tidak dilakukan, hanya di awal kepengurusan saja. Selanjutnya, bulletin biasanya diserahkan kepada yang menanganinya secara penuh walaupun dia hanya satu orang.

Jadi pada dasarnya, pengelolaan bulletin Gema Mujahidin pada aspek pengelolaannya sangat ditentukan secara penuh oleh pengelolanya. Semua pengurus dan siapapun yang ada di boks redaksi terkadang tidak terlibat dalam pengelolaan bulletin Gema Mujahidin. Pada zaman kepengurusan BTM Mesjid Mujahidin di bawah Dikdik Dahlan memang ketua BTM ikut mengurusi dan memantau. Namun selain Dikdik, tidak ada kepengurusan BTM yang melakukan hal tersebut.

Jadi, kondisi objektif pengelolaan bulletin Gema Mujahidin adalah pada tidak adanya kepedulian atau perhatian dari manajemen di atasnya dalam turut menjaga kualitas bulletin Gema Mujahidin. Hal ini pada dasarnya tergantung kasusnya, namun secara garis besar, diakibatkan oleh dua hal, pertama, kurangnya pengetahuan dan kemampuan pengelola BTM Mesjid Mujahidin dalam masalah media massa, khususnya bulletin . Kedua, adanya kepercayaan penuh, sehingga dianggap semuanya akan baik-baik saja.

\section{Konten Bulletin Gema Mujahidin}

Apa yang menjadi konten dalam bulletin Gema Mujahidin setidaknya dapat dilihat dari dasar pemikiran mengapa bulletin Gema Mujahidin itu diadakan. Bagi mesjid Mujahidin, harus diakui bahwa melaksanakan dakwah seringkali mengalami berbagai kekurangan, karena keterbatasan yang ada. Keterbatasan baik pada aspek SDM yang kurang, ekonomi yang sangat terbatas, atas juga fasilitas yang kurang memadai.

Kondisi inilah setidaknya yang menjadi pendorong mengapa dakwah lewat media massa, setidaknya bulletin menjadi penting. Dalam konteks kemodernan, media (khususnya media cetak atau tulis, seperti bulletin ) kini memiliki peran yang sangat penting dan strategis dalam pengembangan dakwah. Dengan tenaga dan biaya yang cukup minimum, dapat diperoleh efektivitas dan jangkauan dakwah yang maksimum. Daya jangkau Media tulis seperti bulletin dapat menembus ruang-ruang luar hingga pelosok. Dengan demikian, media tulis seperti bulletin memiliki 
peran ganda, yaitu disamping dapat membantu dalam memperluas jangkauan berdakwah, juga dapat mempercepat sosialisasi dan publikasi program-program masjid. Karena itu melalui penerbitan media ini, akan menjadi mobil penggerak dakwah masjid.

Setidaknya, keberadaan bulletin Gema Mujahidin bagi mesjid bertujuan untuk memperluas jangkauan dakwah dan sosialisasi program mesjid. Selain itu, bulletin Gema Mujahidin juga bertujuan agar menjadi media ibadah, dakwah dan pencerahan peradaban. Konsumen yang menjadi target sasaran minimal jama'ah jum'at Masjid Raya Mujahidin $( \pm$ 3000 jama'ah) serta jama'ah masjid-masjid yang terjangkau $( \pm 2000$ jama'ah).

Untuk memenuhi kebutuhan dakwah yang disebarkan mesjid Mujahidin, bulletin Gema Mujahidin setidaknya menyediakan lima rubrik yang siap diisi, seperti artikel utama yang berisi karangan popular yang bertemakan keagamaan. Kedua kolom atau fikrah yang bersisikan tulisan ringan yang bersifat reflektif berkenaan dengan fenomena sosial yang actual di masyarakat. Selain itu, disediakan juga informasi seputar kegiatan masjid dan khatib Jum'at. Untuk menerima feed back dari jamaah, bulletin Gema Mujahidin juga menyediakan kolom konsultasi agama. Sedangkan untuk menampung sponsor, pengelola bulletin menyediakan rubrik iklan di halaman akhir.

Konten bulletin Gema Mujahidin disesuaikan dengan visi-misi mesjid mujahidin yaitu sebagai pusat ibadah, dakwah dan pencerahan peradaban. Sedangkan secara manajemen keorganisasian, visi-misi itu juga akan sangat bersinggungan dengan Ormas yang membawahinya yaitu Muhammadiyah.

Dari aspek misi, bulletin Gema Mujahidin berkepentingan untuk melakukan tiga hal, pertama, menyebarkan dakwah bi al qalam. Kedua, membangun citra mesjid yang lebih mencerahkan pemikiran masyarakat. Ketiga, sebagai sarana publikasi agenda dan kegiatan mesjid. Dari tiga misi inilah kemudian pengelola bulletin Gema Mujahidin melakukan kreasi yang lebih dinamis.

Menurunkan dari visi-misi mesjid Mujahidin, bulletin Gema Mujahidin lebih mengoperasionalkannya dengan lebih membumi. Karenanya pada hakikatnya tetap sejalur walaupun ada improvisasi di sana-sini. Sedangkan perubahan bentuk lay out dan aspek seni yang lain di dalamnya, merupakan upaya untuk tetap bulletin Gema Mujahidin bisa lebih menarik dari sisi tampilan. 
Pada tahun 98-an, bulletin Gema Mujahidin pernah menurunkan materi tentang Pedoman Hidup Islami Warga Muhammadiyah (PHIWM) secara berseri. Selain itu sesekali bulletin Gema Mujahidin juga memuat keputusan-keputusan Muktamar dan Tanwir Muhammadiyah yang sekiranya penting dan mendesak untuk disebarluaskan.

Pada zaman Dikdik itulah, warna kemuhammadiyahan sedikit menonjol, kendati tahu bahwa jamaahnya bukan hanya dari Muhammadiyah. Namun sebagai bulletin yang berada di bawah Muhammadiyah, bulletin Gema Mujahidin juga berkepentingan untuk menyampaikan pesan-pesan Muhammadiyah secara langsung.

Pada zaman ini pula warna Muhammadiyah selain dari aspek keputusan-keputusan persyarikatan secara langsung seperti di atas, juga aspek penulis yang secara formal diberi kesempatan kepada para pengurus Muhammadiyah. Karenanya, sangat wajar pada zaman ini bulletin Gema Mujahidin lebih menonjolkan Muhammadiyahnya.

Warna internal persyarikatan juga dapat dilihat pada rubrik kolom. Kendati bukan orang-orang structural Muhammadiyah yang mengisi, namun rubrik ini setiap terbitannya diisi oleh Dikdik sendiri, yang notabene jelas kader Muhammadiyah itu sendiri. Karenanya, kendati tidak menamakan diri sebagai pengurus Muhammadiyah, namun nilainilai kemuhammadiyahannya pasti akan sangat menonjol.

Aspek keterbukaan sendiri sebenarnya dilakukan oleh Dikdik ketika secara kebijakan bulletin Gema Mujahidin membuka kesempatan kepada jamaah lain untuk mengisi topik utama. Namun, keberadaan penulis pun tetap harus melalui proses seleksi yang ketat.

Pada dasarnya, yang menjadi pertimbangan, bukanlah siapa yang menulis, tetapi lebih kepada isi tulisan. Walaupun yang nulis itu orang Muhammadiyah, tetapi jika tidak sesuai dengan standar Bulletin Gema Mujahidin maka tidak akan dimuat. Sebaliknya, walaupun bukan orang Muhammadiyah tetapi memenuhi standard Bulletin Gema Mujahidin maka akan dimuat.

Di antara kriteria tulisan yang akan dimuat di Bulletin Gema Mujahidin adalah tulisan-tulisan yang sifatnya menyejukkan hati. Pengelola sadar bahwa salah satu fungsi mesjid adalah memberikan ketenangan kepada jamaah. Karenanya, secara terbalik, pengelola bulletin Gema Mujahidin sangat memprotek terhadap konten yang cenderung memprofokasi atau memanas-manasi jamaah.

Pengembangan konten bulletin Gema Mujahidin diarahkan pada tema-tema yang lebih terarah, seperti permasalahan akhlak, pemikiran 
Islam, masalah sosial, budaya dan tema-tema aktual lainnya. Tema-tema ini dikemas dalam bentuk tulisan yang bersifat tuntunan hingga kritis. Sajian tulisan seperti ini selain untuk kepentingan memberikan kesejukan, juga memberi daya kritis masyarakat akan kondisi sosial yang ada di sekitarnya.

Pengelola pasca Dikdik ini yaitu Isa Nur Zaman memiliki corak baru yang lebih reflektif kritis. Konten-kontennya tidak begitu memperdulikan siapa yang menulis tetapi sejauh mana konten itu dapat memberikan perubahan kepada masyarakat. Pada aspek penulis, memang hampir mirip dengan masa Dikdik, dimana konten menjadi pertimbangan. Hanya saja, kualitas tulisan yang dimaksud oleh Dikdik dengan Isa menjadi berbeda. Perbedaan pada tema dan arah tulisan. Namun, Dikdik masih memberikan peluang untuk munculnya penulis atau tulisan-tulisan tentang Muhammadiyah, namun Isa lebih cenderung substansi yang diambilnya bukan putusan-putsan formal organisasinya.

Karenanya, dalam perkembangan materi dari bulletin Gema Mujahidin lebih mengarah kepada substansi materi yang bersifat reflektif tanpa harus terjebak pada formalitas organisasi. Sehingga tema-tema yang diangkat memang sesekali melihat aspek aktualitas yang ada di masyarakat. Walaupun aktualitas bukan berarti seperti berita biasa, namun hari-hari besar yang terjadi pada minggu itu. Kemudian dari peristiwa aktual itu disorot dari pandangan kritis penulis yang telah diseleksi oleh pengelolanya.

Namun, bobot yang paling penting untuk disampaikan dalam bulletin Gema Mujahidin ini adalah aspek kualitas tulisan. Kualitas memang pada dasarnya sangat abstrak dan sulit diukur. Namun setidaknya, dalam pandangan pengelola bulletin Gema Mujahidin, berkualitas dalam arti semua konten akan selalu mengacu pada kepentingan visi dan misi mesjid yang perlu disampaikan.

Aspek kualitas ini, tentu kemasannya akan bermacam-macam, penulisnya bisa siapapun, dan sumbernya bisa dari manapun. Yang paling penting dari semua itu adalah bagaimana konen itu memberikan sesuatu yang berarti bagi jamaah. Walaupun ada yang mempersoalkan dari aspek sumber tulisan, namun bulletin Gema Mujahidin pada zaman Isa ini tidak ingin "mengharamkan" tulisan yang bersumber dari buku, internet, atau orang-orang yang telah tiada (meninggal). Selama konten itu mengarah pada pencerahan dan tidak keluar dari visi misi mesjid, tidak menjadi persoalan. 
Dari sisi penjadwalan penulis, sejak awal tidak ada penjadwalan khusus buat penulis. Namun pada zaman Dikdik lebih terjadwal karena ada bagian-bagian setiap minggunya yang harus diisi oleh orang-orang tertentu. Pada zaman Isa lebih bebas dan tidak memberikan tugas khusus kepada orang-orang tertentu untuk ngisi bulletin. Walaupun sebenarnya hampir mirip dari aspek pengisi, secara formal semuanya akan mengatakan bahwa para pengisi adalah mereka yang berasal dari unsure Muhammadiyah, unsure pengurus mesjid Mujahidin, tokoh masyarakat, dan membuka peluang bagi masyarakat umum.

Namun, secara terbuka pengelola bulletin Gema Mujahidin pada periode akhir ini menjelaskan bahwa sumber tulisan itu selain dari orangorang yang telah disebutkan di atas, juga dapat diambil dari internet dan buku-buku yang ada. Keterbukaan pengelola bulletin Gema Mujahidin ini menyangkut aspek kreativitas yang ada di lingkungan Muhammadiyah dan mesjid yang tidak semuanya bisa diandalkan untuk menulis, terlebih yang sesuai dengan visi-misi yang telah ditentukan. Akhirnya pengelola bulletin harus mencari sendiri dengan mencari dari berbagai sumber.

Dari sisi konten bulletin Gema Mujahidin juga, kita bisa melihat dari aspek kriteria yang dibuat oleh pengelolanya. Kendati tidak memiliki jadwal tema yang akan dibuat setiap minggunya, namun pengelola bulletin Gema Mujahidin memiliki kriteria umum tulisan yang harus dimuat di bulletin Gema Mujahidin. Diantara kriteria penting itu adalah tidak adanya unsure konflik baik dalam penulisan judul maupun isi tulisan.

Selain itu, untuk mempertegas identitas bulletin mesjid, kriteria tulisan di bulletin Gema Mujahidin juga diwajibkan ada al-Quran dan atau hadits yang diambil sebagai sumber rujukan tulisan. Kemudian, karena tidak banyak ruang untuk konten, pengelola juga lebih memprioritaskan tulisan yang langsung fokus pada inti masalah, tidak berbelit-belit dan jelas isinya.

Sebaliknya, pengelola bulletin Gema Mujahidin tidak akan memuat tulisan yang bernuansa konflik ke dalam bulletin nya. Hal ini dilakukan karena pengelola bulletin Gema Mujahidin menganggap bahwa bulletin nya memiliki kepentingan untuk memberikan kesejukan bukan mengompori jamaahnya.

Lebih maju dari itu, pengelola bulletin Gema Mujahidin menginginkan bahwa segala pesan yang disampaikan di medianya merupakan substansi dari niali-nilai dari agama Islam, bukan seruan yang sifatnya formalisme. Dengan demikian, pengelola bulletin Gema 
Mujahidin berharap bahwa pesan-pesan yang ada di dalamnya dapat memberikan solusi bagi kehidupan.

Secara inklusif, pengelola bulletin Gema Mujahidin juga membuka peluang untuk terjadinya diskursus pemikiran yang lebih luas. Inklusifitas konten dapat dilihat dari para penulis dan wacana yang dimuat di bulletin ini kendati sebagian orang menganggapnya sebagai orang-orang yang dianggap liberal. Namun bagi pengelola bulletin Gema Mujahidin, media massa kecil seperti bulletin Gema Mujahidin juga memiliki kepentingan untuk memberikan pencerahan dengan berbagai pemikiran inklusif, dengan keragaman pemikiran yang sangat terbuka. Wacana-wacanan keragaman terbuka kendati tatap goals nya adalah dalam rangka membuka wawasan kritis akan pentingnya Islam yang berkemajuan, memberikan solusi terhadap permasalaan sosial, dan caranya tentu dengan jalan damai bukan kekerasan.

Jadi, model wacana kritis yang dikembangkan pengelola bulletin Gema Mujahidin, terutama pada masa Isa, merupakan perspektif baru pengelola bulletin dengan maksud memberi pandangan baru kepada jamaah akan pentingnya mengkritisi kondisi sosial yang ada, namun tetap berada dalam kondisi anti konflik. Ini adalah salah satu misi pencerahan yang dilakukan oleh pengelola bulletin Gema Mujahidin dalam rangka membangun peradaban yang lebih baik.

\section{PENUTUP}

Aspek kesejarahan bulletin Jum'at tidak bisa dipisahkan dari keberadaan mesjidnya, termasuk dalam persoalan arah dakwah yang menjadi konten bulletin Jum'at tersebut. Dari sisi konten, bulletin Jum'at sangat erat dengan orientasi atau corak dakwah yang dilakukan oleh mesjidnya.

Berbeda dengan media massa pada umumnya, bulletin Jum'at pada aspek pengelolaan tidak banyak melibatkan banyak orang. Kalaupun ada keterlibatan pihak lain, itu sangat terbatas. Karenanya, bulletin Jum'at biasanya lebih didominasi oleh orang tertentu yang diberi kepercayaan oleh pengurus mesjidnya untuk mengelola bulletin Jum'at.

Keberhasilan bulletin Jum'at akhirnya sangat ditentukan oleh individu yang diberi tanggungjawab mengelola bulletin Jum'at. Termasuk dalam konteks ini adalah bagai mana konten bulletin Jum'at juga sangat ditentukan oleh sejauhmana pemahaman pengelola bulletin Jum'at terhadap visi-misi mesjidnya. 
Sejauh ini konten bulletin Jum'at yang menjadi objek penelitian yaitu bulletin Uswah Pusdai Jabar dan bulletin Gema Mujahidin, memberikan pesan-pesan yang jauh dari unsure kekerasan atau memberikan pemahaman yang ekslusif. Walaupun bulletin Uswah Pusdai Jabar lebih ingin moderat dan menyampaikan ajaran Qur'anSunnah, namun hal itu disampaikan dengan kemasan bahasan yang halus. Pemberantasan bid'ah, khurafat dan tahayul, tidak disampaikan secara tegas. Di sisi lain, bulletin Gema Mujahidin memberikan pesan-pesan tentang arti penting toleransi dengan memberikan pemahaman kritis tentang kondisi sosial masyarakat. Karenanya dengan tetap bersumber Qur'an dan Sunnah, pengelola bulletin ini berharap masyarakat akan lebih mementingkan persoalan bersama dari pada hanya ekslusif dan cenderung keras dalam menyampaikan pesan.

Selama ini Jawa Barat dikenal dengan daerah rawan konflik khususnya dalam hal isu keagamaan. Namun, daerah di mana tempat dua bulletin yang diteliti ini berada, termasuk daerah penyebarannya hingga ke Kabupaten Bandung, tidak pernah terjadi konflik dengan isu agama. Kendati sumber pemahaman Islam tidak hanya dari bulletin Jum'at, namun setidaknya dengan pesan-pesan yang lebih toleran di dua bulletin yang diteliti, sedikit banyak memberikan kontribusi terhadap terjadinya kerukunan ummat beragama di Jawa Barat khususnya Kota dan Kabupaten Bandung.

\section{DAFTAR PUSTAKA}

Eriyanto (2002), Analisis framing: konstruksi, ideologi, dan politik media. Yogyakarta: LKiS Pelangi Aksara.

Hikmat, Mahi M. (2011), Etika dan Hukum Pers, Bandung: Batic Press.

Kahmad, Dadang (2011), Multikulturalisme dalam Perspektif Islam, Bandung: Pustaka Al Kasyaf.

Kusnawan, Aep (2004), Komunikasi dan Penyiaran Islam, Bandung: Benang Merah Prss.

Kusumaningrat, Hikmat dan Purnama Kusumaningrat (2005), Jurnalistik Teori dan Praktik, Bandung: Rosda.

Moloeng, Lexy J. (1998), Metodologi Penelitian Kualitatif, Bandung: Rosda. Nurudin (2007), Pengantar Komunikasi Massa, Jakarta: Rajawali Press.

Oetama, Jakob (1987), Perspektif Pers Indonensia, Jakarta: LP3ES. 
Romli, Asep Syamsul M. (2003), Jurnalistik Dakwah; Visi dan Misi Dakwah Bil Qalam, Bandung: Rosda.

Suhandang, Kustadi (2004), Pengantar Jurnalistik; Seputar Organisasi, Produk dan Kode etik, Bandung: Nuansa.

Sumadiria, Haris (2005), Jurnalistik Indonesia; Menulis Berita dan feature, Bandung: Rosda.

www.wikipedia.com/kebijakan, kebijakan, diunduh Senin (7/5) pukul $20.00 \mathrm{WIB}$.

www.satrioarismunandar6.blogspot.com, 2012, Peran Media Massa, diunduh Senin (7/5) pukul 12.30 WIB.

270 Ilmu Dakwah: Academic Journal for Homiletic Studies, Vol. 10 No.1 | Jan-Juni 2016 